\title{
Moral Education: Current Values in Students and Teachers' Effectiveness in Inculcating Moral Values in Students
}

\author{
Vaishnavi. R. Kanzal ${ }^{1 *}$, Subikshalakshmi. G ${ }^{2}$ Lopamudra Goswami ${ }^{3}$
}

\section{ABSTRACT}

Moral values play an important role in every aspect of an individual's life. It is necessary for the holistic growth of an individual. According to Piaget's theory of moral judgment, adolescence is the phase where the transition from heteronomous to autonomous morality takes place. During this transition period, the role of educators becomes crucial, as most of the learning in that phase occurs at school. Despite moral education being provided in schools, there is a substantial increase in delinquency. This evokes a question whether teachers inculcate moral values effectively in students. This study focuses on measuring the current moral values in students, the effectiveness of teachers in inculcating such moral values and whether there is effective implication of the learnt moral values. Sampling method was random and the sample size of the students and their moral science teachers are 102 and 12 respectively. The age range of the students was between 12 and 14. The tools used were Moral Values Scale (MVS), Personal Values Scale (PVS) and Teachers’ Effectiveness Scale (TES). The result from that quantitative analysis revealed that the current level of moral values in students range from high to extremely high. The teachers are very effective in inculcating moral values in the students. The relationship between teachers' effectiveness in inculcating moral values and the current moral values in students is positive, but negligible. But, the qualitative observation revealed that there is an immense gap between the theoretical knowledge of moral values of the adolescent students and the practical implementation of the same. Further studies will be focused on strategies that could encourage practical implementation of moral values through moral education in their real life situations.

Keywords: Moral values, Teacher effectiveness.

\footnotetext{
${ }_{1}^{1}$ Associate Counsellor at Cytecare Cancer Hospitals, Bangalore, India

${ }^{2}$ Ex - student of Montfort College, Bangalore, India

${ }^{3}$ Assistant Professor, Montfort College, Karnataka, India

*Responding Author

(C) 2016 Vaishnavi R K, Subikshalakshmi G, Lopamudra G; licensee IJIP. This is an Open Access Research distributed under the terms of the Creative Commons Attribution License (http://creativecommons.org/licenses/by/2.0), which permits unrestricted use, distribution, and reproduction in any Medium, provided the original work is properly cited.
} 


\section{Moral Education: Current Values in Students and Teachers' Effectiveness in Inculcating Moral Values in Students}

For the past few years, it has been witnessed that there is a steady increase in delinquency. According to the National crime records Bureau, cases involving juvenile offenders have increased by $18 \%$ as registered in 2014. Quoting a study, mental health experts said there has been a $300 \%$ increase in the number of children committing heinous crimes in the past three years.

"In the year 2014, a total of 33,526 cases (under IPC) were registered against children below 18 years of age, as against a total number of 28,51,563 cases registered in the country during that year" (The Indian Express, Aug 20, 2015). According to the State Crime Records Bureau, Tamilnadu, $95 \%$ of delinquents live with their parents, and only $5 \%$ of juvenile offenders were homeless.

The five broad institutions of society - Family, Religion, Politics, Economics, and Education, play an important role in the development of an individual and their behaviour. Every institution teaches several aspects, which constitute moral values, on its own way. They emphasize on the norms, which are socially expected out of every individual to maintain harmony among human beings and in the social world.

Moral values play an important role in every aspect of an individual's life. It is necessary for the holistic growth of an individual. Moral values involve "social education which covers the way the individual deals with other members of the community" (Sarangi, 1996, p. 1). It is also a responsible attitude towards others and an understanding of right and wrong behaviour, expected by the norms of the society.

Although, both personal and situational factors like parenting, temperament, socio-economic background have influence any kind of human development which are inevitable, this study focuses only on moral values provided by educational institutions, in the name of moral education based on the premise that there is less effective implementation of such learning. It is to be recognized that children spend majority of their time at school. So it is to be understood that "A school is not merely a teaching shop, but a place which transmits values and attitudes" (Sarangi, 1996, p. 156).

In a small community called school, a teacher has to train his/her students to deal with the actual society effectively. Moral education is an important aspect which a teacher has to stress upon as "it is this teacher who confronts the students in the age group 6 to 15 years where they respond to the teacher more than any one else including their parents" (Sarangi, 1985, p.13).

The school curriculum, rules of the school, co-curricular activities, personality of the educators, school environment as a whole influence the development of the children including their moral

(c) The International Journal of Indian Psychology, ISSN 2348-5396 (e)| ISSN: 2349-3429 (p) | 175 


\section{Moral Education: Current Values in Students and Teachers' Effectiveness in Inculcating Moral Values in Students}

development. Therefore, schools could also be effective resources in inculcating moral values in children. Moral education benefits the society in general and also the student in particular. It can be a stepping-stone for a peaceful life.

Despite moral education being provided in schools, there are non-harmonious incidences occurring in the society. This provokes a question, 'Where do we lack in teaching and inculcating moral values in students?”. This question gave rise to this study of teachers' effectiveness in inculcating moral values in students where the idea is to assess the current level of moral values in adolescent students and also check the effectiveness of teachers in inculcating such moral values.

Some of the theories that describe the moral development in children include, Piaget's theory of moral development, Kohlberg's levels of moral development and Einsberg's theory of pro-social moral reasoning.

1. Piaget's theory (1932): He described two stages of moral development, which are heteronomous morality and autonomous morality.

Heteronomous morality is the stage where the child will have intellectually immature morality. Here, the child understands the importance of rules of behaviour and follows them. The child also associates obedience to rules of behaviour with rewards and non-obedience with punishment.

Autonomous Morality is the stage where the transition occurs. It occurs during late elementary school age or adolescence. Here, though the child understands the rules of behaviour, the child learns that those rules are not absolute. He/she realizes that such rules are products of mere social interaction and are likely to change if majority exists.

2. Kohlberg's Theory (1958): He describes it in three levels, and the two of which are focused. Pre-conventional level (Around 9years): In this level, rules and expectations are imposed from outside. The child still considers the self first, but also recognizes the fact that others have rights.

Conventional Level (adolescents and adults): The moral judgment is shaped by consequences of himself and the members of the group, family or nation at large.

3. Einsberg's theory (1980): In 1980s, Einsberg identified six stages of pro-social moral reasoning. The research samples fall under third and fourth level of this theory

Stereotyped and/or Approval-oriented reasoning (Level 3 - secondary school students): The orientation is interpersonal and stereotyped. The concern and acceptance of others are used in justifying pro-social behaviours. 


\section{Moral Education: Current Values in Students and Teachers' Effectiveness in Inculcating Moral Values in Students}

Empathetic reasoning (Level 4 - Secondary School students and older): The orientation is self reflective and empathetic. The concern for others stems from consequences of his/her action. $\mathrm{He} / \mathrm{she}$ does it because he/she feels good.

Thus, these are the three theories that well describe the moral development in adolescents, based on which the study was preceded.

\section{Rationale:}

This study will aid in knowing the current level of moral values in adolescent students, knowing whether teachers are effective in providing moral education, and knowing whether the implication of learning occurs or not. The knowledge of this will be helpful in training teachers for effective ways of teaching and also train the students in implementation of the learnt moral values. On a large note, the study could benefit the society by bringing to light one of the causes of delinquent behaviour and also certain recommendations to reduce the same.

\section{REVIEW OF LITERATURE}

A Review is the critical appraisal of the precious studies and it helps to know the different areas covered by various studies in the field of investigation of the researcher. To do a particular research, current knowledge of that particular field is essential.

The objective of this study was about the formation in moral values at the mid-superior level (1118 years old). The study was based on a documental analysis and the opinions provided by few international organizations in the field of education. The result emphasized on the inclusion of formation in moral values by the transversal axis and the integrated curriculum. (Martinez, B., Jose, J., Arganis, L., Maritza, J., 2013).

The purpose of this study was to understand how to provide values education in elementary education and have teachers' views on it. Participants of the study consisted of six teachers giving values education. The data were collected with semi-structured interviews, and were content-analyzed. The results showed that participants have difficulties in planning, implementing and evaluating values education lessons in respect to learning outcomes, content, instructional materials, activities and methods. (Sahinkayasi, Y., Kelleci, O., 2013).

The aim of this study is to investigate teachers' perceptions of their practice of values education, and to review their degree of professionalism in the same. Qualitative interviews with 13 teachers have been conducted. Comparative analysis was done. According to their view, values education is (a) most often reactive and unplanned, (b) embedded in everyday school life with a focus on students' everyday behaviour in school, and (c) partly or mostly unconsciously performed. Furthermore, professional knowledge appears to be missing in the area of values education among these teachers. (Thornberg, R., 2008). 


\section{Moral Education: Current Values in Students and Teachers' Effectiveness in Inculcating Moral Values in Students}

An exploratory study had focused on the preparation of student teachers for moral education. The teacher educators who carried out the curriculum and the student teachers who participated in it, were asked whether they recognized the moral aspects of the curriculum as designed. Finally, the effects of the curriculum on the learning of the student teachers were tested, using a pre- and post- test. The results of the study led to the conclusion that more attention is needed to the implicit and unplanned aspects of preparing students teachers for moral education. (Willemse, M., Lunenberg, M., Korthagen, F., 2005).

The purpose of this study was based on the hope that the findings from moral psychology will lead to best practices in moral education. The moral and character education literatures were selectively reviewed and some of the challenges that have been faced were highlighted. Then, the moral identity literature was reviewed and a new found model of moral identity formation emphasizing the "characteristic adaptations" were offered (i.e., moral orientation, moral self, moral emotions, and social relationships and opportunities). Finally, how some of these "characteristic adaptations" could be used in the development of successful moral education programs were explained. (Matsuba, M. K., Murzyn, T., Hart, D., 2011).

This article investigates the role of teachers for moral and affective education of children in secondary education, in Romania. The objectives are, to identify current challenges and difficulties faced by teachers and students in relation to moral and affective education in school, to review how teachers understand their role, to identify critical areas of teacher training and solutions for improvement. It emphasizes the need to update educational practices, while the fast changes of the education system in the last decades caused an increased resistance of school. (Velea, S., Farca, S., 2013).

The aim of this research is to study the effectiveness degree of active teaching methods (contemporary methods leaving conventional methods) on religious and moral education at recognition, emotional and behavioural aspects of students at primary school. Research sample is 103 teachers (men\& women) of fifth grade in primary school who were selected randomly. Selfreport measure was used for data collection. Results revealed that active teaching methods have effect on religious and moral education at Recognition, Emotional and Behavioral aspects of students at fifth grade of primary school. (Gholami, A., Maleki, H., Rizi, C. R., 2011).

A study was conducted to determine the level of morality among adolescents and to assess it as a function of their age and gender. The sample consists of 160 adolescents in of age group between 13 and 18 years. Half of these adolescents were in the early adolescence (13-15 years) and rest in the late adolescence (16-18 years) age range. The sample was selected by random sampling procedure from rural areas of Samba District, Jammu, J\&K. The standardized Moral Values Scale was used for data collection. The result shows that majority of the samples had moderate to

(c) The International Journal of Indian Psychology, ISSN 2348-5396 (e)| ISSN: 2349-3429 (p) | 178 


\section{Moral Education: Current Values in Students and Teachers' Effectiveness in Inculcating Moral Values in Students}

low morality level. None of the sample adolescents had very high morality and those who have high moral values were also few in number. Early adolescents had significantly higher levels of morality than late adolescents as revealed by statistical procedures. However, no significant differences were found in the moral values of boys and girls. The results highlight that the age of adolescents has significant influence on their morality levels. (Dr. Sarika Manhas \& Ms. Ravina Kousar, 2012).

"When values are taught at a tender age, they remain with then forever. Classroom is only used for discussion, but the values we teach are in fact experimented outside class. The bottomline is that apart from academics, children need values.” says Mayank, founder of Val-Ed.Schools are currently encouraging val-ed (value education) classes, to the students where students discuss the unique positive qualities of mythological characters. From Mahabharata to current day scenario, the students discuss various issues related to life. Val-Ed is a social enterprise, which aims at teaching values to schoolchildren. It was launched in August 2013 by Mayank Solanki and has collaborated with several colleges and schools in Bengaluru and Belagavi. The classes include story telling, watching videos and discussions to help students develop elocution skills, confidence and interactive skills.This method of teaching values has also helped children deal with matters at home and some parents have pointed at positive behavioural changes in their children. (Rao S, 2016).

\section{METHODOLOGY}

\section{Objectives:}

1. To measure the current level of moral values in adolescent students.

2. To measure the effectiveness of teachers' in inculcating moral values in students.

3. To find whether the there is a relationship between the first and the second objectives.

4. To find whether the practical implementation of theoretical leaning occurs.

\section{Hypothesis:}

There is a relationship between teachers' effectiveness in inculcating moral values and moral values possessed by adolescent students. (The higher the teachers' effectiveness in inculcating moral values, the higher the moral values possessed by adolescent students).

\section{Participants/ Sample size:}

The participants for the study comprised of 102 adolescent students, both boys and girls, of age between 12 and 14, and 12 moral education teachers.

\section{Tools Used:}

For data collection, three standardized scale were used. 


\section{Moral Values Scale (MVS)}

MVS was developed by Alpana Sen Gupta and Arun Kumar Singh. It consists of 36 items, the students are asked to read the question carefully and ask to place tick mark on either yes or no. A score of +1 is given when correct response is provided. A score of 0 is awarded for all other answers. The maximum possible score for the scale is 36 . Thus the high score on this scale indicates high moral values and low score indicates low moral values on the part of the participant.

\section{Personal Values Scale (PVS)}

PVS was developed by Madhulika Verma and Vindeshwari Waxar Pawar. This scale consists of 50 items divided into 8 value areas namely: Honesty, Love, Helpfulness, Courage, Good manners, Faithfulness, Discipline, and Cleanliness. This test is developed for population between $12-16$ years of age.

\section{Teachers Effectiveness Scale (TES)}

Umme Kulsum developed TES. This self anchoring scale, consists of 60 items and claims to measure five areas of teacher effectiveness namely, preparation and planning for teaching, classroom management, knowledge of subject matter, personality characteristics, and interpersonal relations all comprising 60 statements.

The split half reliability coefficient is .82 and test-retest reliability coefficient is .79. The validity coefficient of the scale is .85. It is standardized on secondary school teachers.

\section{Procedure:}

The entire study was carried out in 10 schools in Bangalore. 10 students were randomly chosen from 7th and 8th standard from each school and their respective moral education teachers. The students were aged between 12 and 14. The schools in Bangalore were selected using convenient sampling method. Students from each school were selected using simple random sampling method. The tests were group administered to students and the responses were self-reported with close-ended questions. TES was individually administered to the teachers.

\section{Statistical Analysis:}

The data collected was complied and the mean score was interpreted to find the current level of moral values in adolescent children and the effectiveness of the teachers. The strength of the relationship between the teachers effectiveness in inculcating moral values and the moral values in the students was interpreted using Pearson product moment correlation.

\section{ANALYSIS AND INTERPRETATION}

The following tables show the strength of relationship between moral values in students and the teachers' effectiveness in inculcating the same. 
Moral Education: Current Values in Students and Teachers' Effectiveness in Inculcating Moral Values in Students

Table 1 shows that correlation between MVS and TES data:

\begin{tabular}{|l|l|l|l|}
\hline \multicolumn{2}{|l|}{ Correlations } & \multicolumn{3}{l|}{} \\
\hline \multirow{3}{*}{ MVS } & Pearson Correlation & MVS & TES \\
\cline { 2 - 5 } & Sig. (2-tailed) & 1 & .121 \\
\cline { 2 - 5 } & $\mathrm{N}$ & & .709 \\
\hline \multirow{3}{*}{ TES } & Pearson Correlation & 102 & 12 \\
\cline { 2 - 5 } & Sig. (2-tailed) & .121 & 1 \\
\cline { 2 - 5 } & $\mathrm{N}$ & .709 & 12 \\
\hline
\end{tabular}

Table 2 shows the correlation between PVS and TES data:

\begin{tabular}{|l|l|l|l|}
\hline \multicolumn{2}{|l|}{ Correlations } & \multicolumn{2}{l|}{} \\
\hline \multirow{3}{*}{ TES } & Pearson Correlation & TES & PVS \\
\cline { 2 - 4 } & Sig. (2-tailed) & 1 & .174 \\
\cline { 2 - 4 } & N & & .589 \\
\hline \multirow{2}{*}{ PVS } & Pearson Correlation & 12 & 12 \\
\cline { 2 - 4 } & Sig. (2-tailed) & .174 & 1 \\
\cline { 2 - 4 } & N & .589 & 102 \\
\hline
\end{tabular}

The tables indicate that the strength of relationship between teachers' effectiveness in inculcating moral values and the moral values in the students is positive, but negligible. Thus, it could be understood that there is a relationship between teachers' effectiveness in inculcating moral values and moral values possessed by adolescent students but the relationship is too weak. In other words, the relationship is not very significant.

Table 3 shows the current level of moral values in students and the effectiveness of teachers in inculcating the same

\begin{tabular}{|l|l|l|l|l|}
\hline Tools & MVS & PVS & TES & \\
\hline Mean & 26.93 & 132.88 & 478.16 & \\
\hline Interpretation & High & Extremely High & Most effective & \\
\hline Sample size & 102 & 102 & 12 & \\
\hline
\end{tabular}

(C) The International Journal of Indian Psychology, ISSN 2348-5396 (e) | ISSN: 2349-3429 (p) | 181 


\section{Moral Education: Current Values in Students and Teachers' Effectiveness in Inculcating Moral Values in Students}

The mean score of the students in MVS and PVS scale is interpreted to be 'High' and 'Extremely high' respectively. This indicates that the current level of moral values in the students range from high to extremely high. The mean scores of teachers in the TES is interpreted to be 'most effective'. This indicates that the teachers are very effective in inculcating moral values in students.

\section{FINDINGS AND DISCUSSION}

The findings suggest that the students of age between 12 and 13 have high moral values and extremely high personal values, and their respective moral science teachers' are interpreted to be most effective in teaching and inculcating moral values in students. The correlation between teachers' effectiveness in inculcating moral values and moral values possessed by adolescent students is too low to be significant.

Though the interpretation of quantitative data implies that the students of age between 12 and 13 have high moral values and extremely high personal values, the interpretation from qualitative observation of the samples' behaviour do not correlate with the former. It is evident that the students were able to understand the rules and apply them accordingly in the hypothetical situations that the scales provided. This provokes an inference that, students have the knowledge of moral values, but implementation of those values in their real life situations appears to be inadequate. The qualitative observation of researchers supports this inference and further suggests that the students provided socially desirable responses rather than the one that they desire.

Piaget's theory states that "In the autonomous morality stage, the adolescent not only begins to understand rules but also exercises control over his/her behaviour and acts in accordance with his/her code of ethics, that would have already developed with experience". Here the students' responses were socially desirable though it did not correlate with their behaviour which was observed by the researchers. Some of the students were found copying other's responses despite repeated warning as not to do so. This act is an example of how the behaviour lacks application of learned moral values.

The inference could also be supported by Nancy Eisenberg's theory of moral development, where she has developed different levels of moral reasoning. According to this theory, the sample adolescents fall under the third level of moral reasoning, that is, "Stereotyped/Approval oriented reasoning". This level involves the adolescents' perception of what will gain approval for them from the people around them.

The increase in the juvenile crime rates could be an evident example of lack of application of moral values in real life in the present times. This could be a clear indication of the gap between

(c) The International Journal of Indian Psychology, ISSN 2348-5396 (e)| ISSN: 2349-3429 (p) | 182 


\section{Moral Education: Current Values in Students and Teachers' Effectiveness in Inculcating Moral Values in Students}

acquiring knowledge and application of the same. Considering the national juvenile crime records by National Crime Record Bureau (NCRB) - 2014, it was found that the juvenile crime rate has increased from $1.1 \%$ in 2011 to $1.2 \%$ in 2014. Around 33526 cases of juvenile crimes were reported in 2014 with most of the cases under rape, murder, attempt to murder, robbery, theft, cheating and grievous hurt sections of IPC. The tabular representation of the same is given below:

Table 1: Incidence and Rate of Juveniles in Conflict With The Law under IPC During 2011 2014

\begin{tabular}{|l|l|l|l|l|l|}
\hline Sl no & Year & No of Juvenile Cases & $\begin{array}{l}\text { Total Cognizable } \\
\text { crimes }\end{array}$ & $\%$ & \\
\hline 1 & 2011 & 25125 & 2325575 & 1.1 & \\
\hline 2 & 2012 & 27936 & 2387188 & 1.2 & \\
\hline 3 & 2013 & 31725 & 2647722 & 1.2 & \\
\hline 4 & 2014 & 33526 & 2851563 & 1.2 & \\
\hline
\end{tabular}

Table 2: No. of cases booked under different sections of IPC in 2014.

\begin{tabular}{|l|l|l|}
\hline SI No & Crime & No. of cases \\
\hline 1 & Rape & 1989 \\
\hline 2 & Murder & 841 \\
\hline 3 & Attempt to murder & 728 \\
\hline 4 & Gang rape & 137 \\
\hline 5 & Robbery & 1024 \\
\hline 6 & Kidnapping and abduction & 1455 \\
\hline 7 & Theft & 6717 \\
\hline 8 & Riots & 1089 \\
\hline 10 & Grievous hurt & 1568 \\
\hline 11 & Cheating & 349 \\
\hline 12 & Breach of trust & 47 \\
\hline 13 & Assault on women to outrage her modesty & 1591 \\
\hline 14 & Stalking & 145 \\
\hline 15 & Arson & 64 \\
\hline 16 & Acid attack & 3 \\
\hline
\end{tabular}

(C) The International Journal of Indian Psychology, ISSN 2348-5396 (e) | ISSN: 2349-3429 (p) | 183 


\section{Moral Education: Current Values in Students and Teachers' Effectiveness in Inculcating Moral Values in Students}

Other reasons for dissimulation of the responses were observed to be the fear of being judged/criticized for his/her actual responses and also peer pressure. The students were hesitant to give honest responses for certain questions, as they feared criticism and judgment. Though repeated assurances on confidentiality were given, their belief on this regard was difficult to be changed. The pressure to maintain harmonious relationship with friends made students to help their friends with the responses to be provided on the scales, which evidently proves the existence of peer pressure.

The findings also suggested that the teachers are most effective in teaching moral values. But, on enquiry it was found that the mode of teaching was mere theoretical explanations of concepts and not other effective methods of teaching like visual/auditory aids, group activities, interactive discussions, etc. The teachings were based on the chapters in the textbook and were limited to that in most of the schools. This mode of teaching is against Kohlberg's view, where he states that moral education should be activity based and not just confined to one period. The students should be made to feel the presence of moral values in every class they attend. Such modes of teaching were missing in many schools.

Though the correlation between teacher's effectiveness in inculcating moral values and moral values possessed by adolescent students is negligible, the above paragraph describes the lack of effective methods of teaching by the teachers. Perhaps effective methods of teaching could increase the strength of the relationship. It is also to be noted that students spend majority of their time with teachers, thus effective teaching will play a role in learning.

Considering the above-mentioned observations and discussions, it is inferred that the moral education has been provided to the students by schools and the students have considerable knowledge of moral values. But, there is a lack of effective implication of learned information. Therefore, there is a need for more effective ways of offering moral education in schools. The teaching methodology should not only focus on making the students know the concepts but also focus on making the students aware of the effectiveness of practical implications of such concepts. This is of immense importance because students spend most of their time in schools and teachers could be their role models. So, if the moral acts of teachers are evident in their behaviour then the students are likely to follow the same.

The students should not only be recognized for their academic performance, but also must be recognized for their behaviours through which moral values are exercised. This could be a better method of imparting moral education as experiential learning that could be more useful than theoretical explanations. 


\section{IMPLICATIONS OF THE STUDY}

1. The study examines the role of teachers in inculcating moral education. This could even apply to all the significant adults in a student's life. This calls for a 'Social Change' where adults behave morally and take responsibility for their actions. This strongly contributes to the students of moral education that is not sole the responsibility of schools.

2. The study strongly recommends the recognition and appreciation on being humane. There is a constant pressure on students to perform well academically and their academic achievements are well recognized and appreciated. But, the recognition and appreciation of good deeds of students is very rare. Encouraging good deeds is the need of the present.

3. The study suggests to make moral education compulsory at schools. It was found that many schools did not have any means of imparting moral education, with "lack of faculty" or "not very important" being the reasons for the same. Including moral education as one of the core papers in the curriculum is necessary as this will ensure serious consideration of the subject and will emphasize its importance.

4. The quality of learning should not only be assessed with examinations but should also be assessed with the efficiency of the students to apply their learning in life's situations.

\section{SUMMARY AND CONCLUSION}

The first objective of the research was to measure the current level of moral values in adolescent students. It was found that the current level of moral values ranges from high to extremely high in the adolescent students. The second objective was to measure the effectiveness of teachers in inculcating moral values in students. It was found that the teachers are very effective in inculcating moral values. The third objective was to assess the strength of relationship between teacher's effectiveness in inculcating moral values and the moral values in the students. The relationship is found to be positive, but negligible.

The fourth objective of the study was to study the practical implication of the learnt moral values. There appears to be a immense gap between theoretical knowledge and practical implementation, considering the increase in the Juvenile delinquency in the recent years as per the NCRB reports.

Further research on Moral education will be emphasized on different strategies that could be used to encourage practical implementation of moral education which would build humane qualities in students who are the hope for the future.

\section{Acknowledgments}

The author appreciates all those who participated in the study and helped to facilitate the research process.

\section{Conflict of Interests}

The author declared no conflict of interests.

(C) The International Journal of Indian Psychology, ISSN 2348-5396 (e)| ISSN: 2349-3429 (p) | 185 


\section{REFERENCES}

Bhattacharya S (2015). 2014: 18\% increase in cases. Retrieved from http://indpaedia.com/ind/index.php/Juvenile_delinquency_in_India

Gholami A, Maleki H, C E Rizi (2011).Studying the effectiveness degree of active teaching methods on religious and moral education of students at fifth grade of primary school in Shiraz from teachers' point of view. Procedia: Social and behavioural sciences, 15 (2011), 2132- 2136. doi:10.1016/j.sbspro.2011.04.066

Gross R (2010). Psychology: The science of mind and behaviour. London: Hodder Education.

Jose B M J, Maritza L A J (2013).The Formation in Moral Values in High School Education by Means of the Transversal Axis and the Integrated Curriculum. Procedia: Social and behavioural sciences, 106 (2013), 2807-2816. doi:10.1016/j.sbspro.2013.12.323

Matsuba M K, Murzyn T, Hart D (2011).Chapter 5 - A model of moral identity: Applications for education. Advances in Child Development and Behaviour,40 (2011), 181207.doi:10.1016/B978-0-12-386491-8.00005-0

Ministry of Home Affairs. National Crime Records Bureau (2015). Juveniles in conflict with law: Cases of Juveniles in Conflict with Law under Different Crime Heads of Indian Penal Code(IPC) During 2014 (State/UT-Wise). Retrieved from http://www.ncrb.gov.in/cii2014/Table\%2010.2.pdf

Ministry of Home Affairs. National Crime Records Bureau (2015). Juveniles in conflict with law: Incidence and Rate of Juveniles in Conflict with Law under IPC 2004-2014 (All India). Retrieved from http://www.ncrb.gov.in/cii-2014/Table\%2010.1.pdf 27-12-201

Nucci, L (2015). Moral Development and Education. International Encyclopedia of The Social and Behavioural Sciences, 2 (2015), 775-780. doi:10.1016/B978-0-08-097086-8.92152-4

Periera, A (2015, August 20). 75\% of juveniles held in 2014 were above 16 years of age. Indian Express Online Media. Retrieved from http://indianexpress.com/article/india/crime/75of-juveniles-in-2014-were-between-16-18-years-of-age/

Rao, S. (2016, January 3). Along with math, kids learn about truth \& love. Sunday Times of India, p. 4.

Sarangi R (1996). Moral education in schools: Bases and implications. New Delhi: Deep \& Deep Publications.

Simona Velea, Speranţa Farca (2013). Teacher's Responsibility in Moral and Affective Education of Children. Procedia: Social and behavioural sciences, 76 (2013), 863-867. doi:10.1016/j.sbspro.2013.04.221

Thornberg, R (2008). The Lack of professional knowledge in values education. Teaching and Teacher Education, 24 (7), 1791-1798. doi:10.1016/j.tate.2008.04.004

Willemse M, Lunenberg M, Korthagen F (2005). Values in education: a challenge for teacher educators. Teaching and Teacher Education, 21(2), 205-217.

doi:10.1016/j.tate.2004.12.009 


\section{Moral Education: Current Values in Students and Teachers' Effectiveness in Inculcating Moral Values in Students}

Yunis,Ş \& Ozge, K (2013). Elementary School Teachers' Views on Values Education. Procedia: Social and behavioural sciences, 93 (2013), 116-120. doi:10.1016/j.sbspro.2013.09.162

\section{AUTHOR'S PROFILE}

\section{VAISHNAVI. R. KANZAL}

Vaishnavi R Kanzal is currently working as an Associate Counsellor at Cytecare Cancer Hospitals, Bangalore, India. Her interests lie in the areas of clinical psychology, Psychooncology and social psychology. She is also keenly interested in qualitative research methods. She has been a presenter and has also been a part of the organizing team in the National and International conferences of psychology.

Ph. No.: +91 9741657989

Place: Karnataka, India.

E-mail:kanzal.vaishnavi14@gmail.com

\section{SUBIKSHALAKSHMI. G}

Subikshalakshmi G. is an ex-student of Montfort college. She was a part of Talent2Success Learning Pvt Ltd, where she was managing counselling training programmes. Her interest areas include clinical, social, and positive psychology. She is passionate about conducting research studies. She has made her contributions to National and International conferences as a volunteer from organizing team. She has also been a presenter in an International conference.

Ph. No.: +91 9008574053

Place: Karnataka, India.

E-mail: subiiksha@gmail.com

\section{LOPAMUDRA GOSWAMI}

Lopamudra Goswami is currently working in Montfort College as an Assistant professor. She is also a visiting professor at Martin Luther Christian University for their program on Counselling psychology. Her interests are quiet varied namely in the areas of surrogacy, LGBT community in India and children and women focused research projects. She has been invited to present in internal forums on surrogacy and she has also published two book chapters in lines with the same topic.

Ph.No.: +91 9986998461

Place: Karnataka, India.

E-mail: lopagoswami03@gmail.com

How to cite this article: Vaishnavi R K, Subikshalakshmi G, Lopamudra G (2016), Moral Education: Current Values in Students and Teachers' Effectiveness in Inculcating Moral Values in Students, International Journal of Indian Psychology, Volume 4, Issue 1, No. 81, ISSN:23485396 (e), ISSN:2349-3429 (p), DIP:18.01.138/20160401, ISBN:978-1-365-59365-9 